\title{
Fuelling the Machine: Slave Trade and the Industrial Revolution
}

by Christine Clarke

\begin{abstract}
Some have contested the Industrial Revolution's status as a climactic event bringing social and political upheaval. However, the abolishment of slavery, the destruction of traditional ways of life, and the rise of class-consciousness confirm the climactic nature of this period. In analyzing the dramatic changes in the social organization of British society, this paper aims to reclaim the title of the Industrial Revolution as just that-revolutionary.
\end{abstract}

When the Industrial Revolution "broke out" and the "shackles were taken off the productive power of human societies," ${ }^{1}$ Britain industrialized at a rate that surpassed any other European country. Its successes resulted in a general emulation of British industry by other European countries. The Revolution began in Britain not because of naval superiority or great scientific accomplishments but rather due to a variety of factors including a mild climate, reliable labour force and available markets. However, Industrialization of Britain was not inevitable and its pace was patchy. The British slave trade was the primary factor influencing the influx of capital, resulting in the emergence of a humanitarian movement within Britain. In this paper, I will consider the origins of the spread 26 
of industrialization and the conditions present in the late eighteenth century that allowed Britain to rise as a leading European power. I will then examine factors fuelling the Industrial Revolution including the slave trade, which arguably financed the production of advances in technology and production. Finally, I will look at the overall impact of the spread of industrialization in Britain in terms of its social and political consequences and suggest how the Industrial Revolution re-ordered society and changed the standard of living in Britain. The Industrial Revolution made a lasting impact on the country's social and political landscape.

One might believe that the question of whether the Industrial Revolution deserves its name is not widely disputed in the scholarly community today. The Industrial Revolution as a movement survives in historical memory as a turning point in the history of technological change and has developed into a major component of British identity. It is my conclusion that what distinguishes the Industrial Revolution from most revolutions are the following: (a) it was not one important event but was comprised of various breakthroughs over time, continuing arguably into the present and (b), there was no immediate transformation of British society, which is evident 
when one studies the existing historiography. There is no official date of the commencement of the revolution; in fact, the term was not even used when it began. Eric Hobsbawm maintains that its name "is both logical and in line with a well established tradition." ${ }^{2}$ He disregards what he terms a "fashion among historians" to deny the revolution's existence and states that if it didn't deserve its name then "the word has no commonsense meaning." 3 David Landes expands upon this, listing the improvements made that support the legitimacy of the Industrial Revolution. He suggests that these developments were: the substitution of machines over people, the introduction of unlimited energy produced by engines, and the use of raw materials. ${ }^{4} \mathrm{He}$ champions the revolution as opening "a new age of promise," and as having transformed the "balance of political power, revolutionized the social order...and changed man's way of thinking as his way of doing." 5 Peter Mathias argues that the term 'Industrial Revolution' requires further defining since it theoretically represents an almost impossible age to map out in the long history of technological achievements. Hobsbawm attempts to establish a relative date for the 'take-off' period, and suggests that it took place "contemporary with, but slightly prior to, the French Revolution." ${ }^{6}$ Mathias identifies the problem of using the term 'revolution' 
because the connotation suggests "a very rapid change in a short space of time" and that terms like 'revolution' and 'take-off' are 'over-dramatic.' However, he maintains that it occurred spontaneously and was not the "result of conscious government sponsoring." Patrick O'Brien, Trevor Griffiths and Philip Hunt explain why scholars who study the first Industrial Revolution (between 1688 and 1851) consider it a "much slower and less dramatic discontinuity that several historians have dismissed it as a myth or a misnamed episode in European economic and technological history." 9 These authors characterize the first Revolution as "extensive" rather than "intensive," meaning that there was a larger need for employment or more input vs. factor productivity or industrial output. ${ }^{10}$ When considering the historiography, there is a surprising debate over whether the Industrial Revolution deserves its name. However, there is overwhelming agreement among scholars that it does.

Historians have ample evidence the Industrial Revolution took off in Britain. Previous to the "take off" period, Britain had been preoccupied and "tried to do two things at once -industrialize and fight expensive wars, and she simply did not have the resources to do both." ${ }^{11}$ However, at the end of the French Revolution, Britain had emerged stronger, 
becoming increasingly self-sufficient. This selfsufficiency was made possible by several factors. According to Hobsbawm, Britain's unprecedented success was not due to "scientific and technological superiority, " calling Oxford and Cambridge "intellectually null" and stating that the French had produced "more original inventions....and better ships." 12 Rather, he suggests that Britain had implemented a mechanized factory system to deal with the agrarian problem. ${ }^{13}$ Further, Britain had accessible harbours, a large labour force from a sharp increase in population, a reliable source of capital, mild climate, and availability of markets. The patchiness of industrialization accounts for the "protracted nature of the industrial revolution, viewed as a locus for technological change." ${ }^{14}$ Interestingly, farmers probably witnessed mechanized labour slowly take over since industrialization was intensely regionalized, "leaving large parts of the country untouched." 15 It wasn't a revolution in the traditional sense of the word because there was no great change in a short period of time; "the rate of industrialization was quite slow during the alleged industrial revolution." 16

The large flow of cash from the British slave trade helped to finance industrialization; however, it is 
reasonable to believe that without "overseas expansion, there would have been no Industrial Revolution." 17 Industrialization may have given Britain the incentive for expansion but the slave trade was paying for it. Any positive outcomes of colonization tended to be choked by the "almost unrelieved oppression and brutalization of the indigenous populations." 18 The brutality of the slave trade was not considered because it had been so profitable, especially in Britain. Landes suggests that Britain was emulated because she was "the very model of industrial excellence and achievement." ${ }^{19}$ Indeed many other European countries began to follow Britain's example; France for example targeted Britain for "French entrepreneurs wishing to secure skills and techniques that did not exist in their own country." 20 The slave trade, according to Eric Williams, ended in Britain first not because of pressures from abolitionists, but because it ceased to be economically profitable.

Howard Temperley considers the dispute about the motives behind the abolition of the slave trade, sparked in large part by Williams' thesis in Capitalism and Slavery. Temperley agrees that the slave trade, "as a method of production, was often very successful, providing cheap goods and a high level of 
profits." ${ }^{21}$ In considering the origins of the slave trade, he suggests that "given the choice of employing slaves and toiling for hours in debilitating climates-or indeed, in any kind of climate-settlers generally chose slaves." He argues that this was the case, especially in Britain, because unlike other European countries it was most open to market forces. He maintains that this was not the case in other countries that made slave trade economics something unique in Britain. ${ }^{22}$ Settlers were "[f]reed from the traditional usages and customs of Europe," and "adopted whatever new institutions appeared suited to their needs." ${ }^{23}$ As Temperley considers reasons for the abolition of the slave trade, he suggests one could look for "equally strong economic motives for wanting to get rid of it." ${ }^{24}$ Disagreeing with Williams's assumption that only Adam Smith's Invisible Hand played a role in ending the British slave trade, he instead suggests economic motives are difficult to identify. Evaluating economic reasons for the end of the slave trade is a difficult process because one needs to identify the motives of the key group. Quakers represented a large sect of the abolitionist movement were part of a rather large network of other organizations "devoted to temperance...in fact, to benefiting mankind in almost every way imaginable," who believed that they represented "the triumph of high moral principles over 
narrow sectional interests." 25 The argument of abolition essentially comes down to "the struggle between the rising bourgeoisie and a declining plantocracy." 26 To conclude Temperley's ideas, he suggests that neither economics nor humanitarian influences are very strong arguments on their own. He admits capitalism must have had something to do with the dismantling of the slave system because the abolishment of slavery coincided with the peak of capitalism; popular "[c]apitalist ideas were in the ascendant, and large-scale production of all kinds of goods was beginning." 27 Why then was the slave system abolished? I suggest that the replacement of slave labour must lie behind the Industrial Revolution, which in its literal definition was the "introduction of unlimited energy produced by engines." 28 More abstractly, the Industrial Revolution symbolized an extension of pure capitalist ideology. Using this claim, Temperley suggests that a whole new range of possibilities came into focus and that the ideologies of political economists such as Adam Smith began to view slavery with general hostility. ${ }^{29}$ This is further illustrated by the following passage by Adam Smith:

A person who can acquire no property, can have no other interest but to eat as much, and to labour as much, and to labour as little as possible. Whatever work he does beyond what is sufficient to purchase his own maintenance, can be squeezed 
out of him by violence only, and not by any interest of his own." 30

The ideology put forth by British economists and widely accepted by British industrialists appears to have wholly discredited the slave trade system. Temperley disagrees with Smith's assumption that the desire for labour was motivated by man's want of property. 31 However, Temperley maintains that "freedom and prosperity went hand in hand," suggesting Smith's "hostility to slavery was a natural extension of his general belief in economic freedom." 32 The Industrial Revolution represented in Britain the means to economic self-sufficiency, but it was doing so by exploiting slaves. This, in turn, undermined the system from the bottom. Laissez-faire thinking during the Industrial Revolution no longer supported slavery; in this sense, the Revolution both fuelled and ultimately determined the end of the slave trade.

To further understand the broad impact industrialization, one must also consider that it had profound social and political effects on Britain. As for the social consequences of increased industry, Landes suggests Britain suffered many "growing pains," creating as many hostilities as improvements. While mechanization "opened new vistas of comfort and prosperity for all men, it also destroyed the livelihood 
of some and left others to vegetate in the backwaters of the stream of progress." 33 The Revolution created obvious divisions and bitterness between the rich and the poor, making many resent the capitalist system. The proletariat had not completely emerged but the Industrial Revolution can certainly be credited with bringing it to consciousness. Early hostilities rarely escalated into full-scale riots since peasants, who had become a cheap labour force, often lacked the "organization by which to further political or even economic ends," but would lead to Luddite attacks once class-consciousness was further identified. ${ }^{34}$ Although workers were often united against mechanization, they were not demanding a reorganization of social structure and certainly were not yet united by any common class identity. Factories were sacked when "craftworkers felt threatened by mechanization." 35 Hobsbawm suggests that there would have been an initial increase, but there is no "a priori reason why the standard of living should rise markedly under early industrialization" ${ }^{36}$ He reasons that there would have likely been an initial increase but because the "new rhythm of population" had yet to be formed, it would not have lasted. He does not deny that the Industrial Revolution in the long run brought about a permanent improvement in the standard of living, but there were definite 
disadvantages for the workers who were subjected to harsh and rather dangerous working conditions. ${ }^{37}$

One should also take into account the rapid, natural expansion of the British population. Mathias suggests this was not due to a rapidly decreasing death rate and argues because of increased private burial plots and the inefficiency of the Anglican Church with its "increased pluralism and benefices," the death rate was most likely underestimated by about $25 \%$ so it only appears to have decreased at this time. Furthermore, better medicine and sanitization only helped a very small, privileged group since hospitals were confined to the more prominent towns. ${ }^{38}$ The new average age of maternity fell from 26.5 -33 to 23.5-31 years, meaning that women were healthier and therefore their children were reaching the working and reproductive age groups. ${ }^{39}$ Mathias also argues against factoring a decreasing death rate into the explanation for population growth and that the survival of more children had nothing to do with improved medical equipment and hospitals. He argues instead that lower food prices meant families were likely "buying food and fuel more regularly, if not in greater quantities, and of improved quality." ${ }^{\circ}$ 
More productive machines increasingly displaced artisans. Landes states that the labourers' work now "had to be done in a factory, at a pace set by tireless, inanimate equipment...under the close eye of overseers." ${ }^{41}$ The work available to labourers was unstimulating and routine; they themselves only contributed "one step toward the completion of the final product" so the workers were "little better than slaves at the mercy of their capitalist employers." 42 In that sense, it is little wonder why socialism appealed to the working class.

The Industrial Revolution likewise altered the political landscape in Britain. The emergence of a mass society who, for the most part, viewed capitalism as increasingly unacceptable led to the rise of a more popular socialist attitude, especially among the working class. Indeed, as one maps the increasing production of new machines one can almost watch the progression of socialism. These ideas were arguably rooted in the ideologies popular during the contemporary French Revolution, rather than stemming from Marx, who had not written seriously on the subject until the 1848 uprisings. ${ }^{43}$ The idea that were appealing to the British labourer was a "society of small producers which would take account of social justice... [t]here would be no central state, only self- 
governing communes." 44 These notions also appealed to artisans displaced in the new industrial economy. The socialist system "appealed not only to [the worker's] articulate sense of self-worth but...to their belief that the factory system and machinery were the primary causes of their suffering." ${ }^{45}$ This resulted in a division between "Utopian" socialists and "Scientific" socialists; the Utopians regarded individual liberty as "a mistake, a sin, a grave evil," whereas the scientific socialists "did not reject technology and economic change but saw them as stages along the path of progress." 46 So, what was the extent of the impact of socialism on Britain's working class? Michael Rapport suggests that "political motivation was sparse." 47 The peasant community "defined itself against the intrusion of the outside world, be that in the shape of new (possibly bourgeois) landlords, the developing national economy, or the demands of the state." ${ }^{48}$ Instead, peasant community became conscious of the fact that they were a peasant community capable of defining themselves by what they were not. Rapport upholds that although the peasants attempted to inject politics into their movement, "early signs of peasant politicization were still rare." 49 This supports my assertion that the goals of the peasant community were arbitrary: peasants "hid part of their harvest from the greedy eyes of bailiffs collecting rents or 
dues...they might drag their feet, working at a maddeningly slow pace." ${ }^{50}$ Luddism was the result in many cases and factories may have been damaged or burnt down depending on the extent to which craft workers felt threatened by mechanization. To conclude, it appeared that it was more likely "artisans and craft workers -not the factory 'proletariat' -who were most receptive to radical and early socialist ideas." 51

The major scholarship studied suggests the Revolution deserves its name. It was a 'revolution' in that it introduced an unlimited amount of energy, gradually replacing the working class and rendering the artisans' craft obsolete. After examining the origins of the Industrial Revolution in Britain, it seems there was openness to new technological developments. Britain experienced such a significant increase in population that it was faced with social and political pressures, such as how to maintain a decent standard of living and deal with the growing appeal of socialism. Availability to external markets and relative success in foreign trade made Britain a country to be emulated by other European powers. The slave trade maintained the Revolution and helped to finance and in doing so undermined the whole ideology of capitalism from the bottom. The Industrial Revolution impacted Britain and 
survives in historical memory as one of the greatest achievements in the history of technological development.

${ }^{1}$ Eric Hobsbawm. The Age of Revolution 1789-I848. (London:

Weidenfeld \& Nicolson: 1962), 43.

2 Hobsbawm, 44.

3 Ibid.

${ }^{4}$ David S. Landes. The Unbound Prometheus: Technological Change and Industrial Development in Western Europe from 1750 to the Present, 2nd ed. (Cambridge \& New York: Cambridge University Press: 2003), 41.

${ }^{5}$ Landes, $4 \mathrm{I}$.

${ }^{6}$ Hobsbawm, 44.

${ }^{7}$ Peter Mathias. The First Industrial Nation: An Economic History of Britain 1700-19/4, 2nd ed. (New York: Methuen \& Co.: 1983), 3.

${ }^{8}$ Mathias, 4.

${ }^{9}$ Patrick O'Brien, Patrick et al, Technological Change During the First Industrial Revolution: The Paradigm Case of Textiles, I688-I85I, ed. Robert Fox. (Amsterdam: Overseas Publishers Association: 1996), 156.

10 O'Brien et al, I57.

11 Jeffrey G. Williamson, "Why Was British Growth So Slow During the Industrial Revolution?” The Journal of Economic History 44, no. 3 (Sept 1984); 688 .

12 Hobsbawm, 45.

13 Ibid., 47.

${ }^{14}$ Robert Fox. Technological Change: Methods and Themes in the History of Technology. (Amsterdam: Overseas Publishers Association: 1996), 12.

${ }^{15}$ Asa Briggs \& Patricia Claven. Modern Europe 1789-Present, 2nd ed. (London: Longman, 2003), 5.

${ }^{16}$ Williamson, 689

17 Landes, 37.

18 Ibid., 38.

19 Ibid., 124.

20 Mathias, 12.

${ }^{21}$ Howard Temperley, “Capitalism, Slavery and Ideology” Past \&

Present, no. 75 (May 1977); 94.

22 Temperley, 94.

23 Ibid., 95.

24 lbid., 96.

25 Ibid., 97.

26 Ibid., 100.

27 Ibid., 105. 
28 Landes, 41.

${ }^{29}$ Temperley, 106.

30 Ibid., 107.

31 Ibid.

32 Ibid.

33 Landes, 7.

${ }^{34}$ Rapport, 95.

35 Ibid., 96-8.

${ }^{36}$ Eric Hobsbawm. The British Standard of Living, I790-/850, ed.

Arthur J. Taylor. (London: Methuen \& Co. Ltd: 1975), 59.

${ }^{37}$ Hobsbawm, Standard of Living, 59.

${ }^{38}$ Mathias, 167-68.

39 Ibid., 179.

40 lbid., 172.

41 Landes, 43.

42 Charles Breunig \& Matthew Levinger. The Revolutionary Era: I 789-

1850, 3rd ed. (New York: Norton \& Company: 2002), I48; Breunig \& Levinger, 143.

43 Rapport, 92.

44 lbid., 93.

45 lbid., 96.

46 Ibid., 93.

47 Ibid., 94.

48 Ibid., 95.

49 Ibid., 94.

50 lbid., 95.

${ }^{51}$ Ibid., 96. 